\title{
Threat or Corrective? Assessing the Impact of Populist Parties in Government on the Qualities of Democracy: A 19-Country Comparison
}

\author{
Davide Vittori* \\ Centre d'Etude de la Vie Politique, Université Libre de Bruxelles, Brussels, Belgium \\ ${ }^{\star}$ Corresponding author. Email: davide.vittori@ulb.ac.be
}

(Received 9 September 2020; revised 13 April 2021; accepted 19 April 2021;

first published online 6 July 2021)

\begin{abstract}
Scholars have long debated whether populism harms or improves the quality of democracy. This article contributes to this debate by focusing on the impact of populist parties in government. In particular, it inquires: (1) whether populists in government are more likely than non-populists to negatively affect the quality of democracies; (2) whether the role of populists in government matters; and (3) which type of populism is expected to negatively affect the quality of liberal-democratic regimes. The results find strong evidence that the role of populists in government affects several qualities of democracy. While robust, the findings related to (2) are less clear-cut than those pertaining to (1). Finally, regardless of their role in government, different types of populism have different impacts on the qualities of democracy. The results show that exclusionary populist parties in government tend to have more of a negative impact than other forms of populism.
\end{abstract}

Keywords: populism; quality of democracy; populists in government; Europe

The debate over the definition, the operationalization and the measurement of 'populism' dates back to times when populism was only sporadically used by political scientists and sociologists (Moffitt 2016). Whatever the approach used to describe populism - a thin-centred ideology (Mudde 2004), a communication style (Moffitt 2016), a synonym for political illiberalism (Pappas 2016a), an empty signifier (Laclau 2005), a political mobilization tool (Jansen 2011), a discursive tool (Jagers and Walgrave 2007) - the literature has now dealt with multiple aspects of the populist phenomenon. To name just a few topics, populist attitudes among voters (Castanho Silva et al. 2020), the presence of populism in party manifestos and leader discourses (Hawkins et al. 2018; Rooduijn et al. 2014), populism in party organization (Vittori 2020), the mainstreaming of both left and right populism (Akkerman et al. 2016; Damiani 2020) and populist parties in opposition (Louwerse and Otjes 2019). One of the most debated issues is the relationship

(C) The Author(s), 2021. Published by Cambridge University Press. This is an Open Access article, distributed under the terms of the Creative Commons Attribution licence (http://creativecommons.org/licenses/by/4.0/), which permits unrestricted re-use, distribution, and reproduction in any medium, provided the original work is properly cited. 
between populism and the so-called 'qualities' of (liberal) democracies (Morlino 2011). On the one hand, scholars depict populism as troublesome for liberal democracy (Rummens 2017): populism is considered as inherently conflictual with crucial aspects of this regime, namely pluralism, a mediated form of political representation and the checks and balances between institutions (Abts and Rummens 2007; Pappas 2016b; Urbinati 2013). Other scholars argue that while populism may be a threat, it may also be a corrective for democracy: its presence might foster inclusiveness and highlight legitimate issues neglected by the mainstream, while endangering other aspects of liberal democracies such as public contestation (Rovira Kaltwasser 2012, 2014; Mudde and Rovira Kaltwasser 2012a). Finally, other scholars (Laclau 2005, 2006; Mouffe 2018) hold a much more positive view of populism: in their interpretation, populism is seen as a liberating force for the masses, as it allows instances from below to fill the empty signifier of populism. In this debate, however, with few exceptions (Huber and Schimpf 2016a, 2016b; Rovira Kaltwasser and Taggart 2016; Spittler 2018), comparatively less has been said about the role of populist parties in government and their impact on the qualities of democracy. As populism is growing electorally and several populist parties have gained access to government (Akkerman et al. 2016), it is worth investigating their impact on the political regime in which they operate. The research questions that this article aims to answer are: (1) whether populism impacts (negatively or positively) the qualities of (liberal) democracy; (2) whether the impact changes depending on the role that populists have in government; and (3) whether a specific type of populism is more harmful than others. While the literature has already dealt with the first aspect, the second and the third aspect are less investigated by comparison (see below).

This article is structured as follows: the first part briefly outlines the distinction between the types of populism and their electoral trajectories in the past few decades. It goes on to review the literature on the relationship between populism and liberal democracy in order to set up three hypotheses related to the threator-corrective thesis. The following empirical section is divided into three parts, one for each hypothesis outlined in the previous section: using longitudinal data from the Global State of Democracy Index (GSoDI), it shows that populist parties in government significantly and negatively affect almost all qualities of democracy under analysis. Yet, the hypothesis that the more relevant the role of the party, the higher the impact is not confirmed in toto. Evidence also shows that, with some nuances, exclusionary populist parties in government impact more negatively than other forms of populism and non-populist governments.

\section{Defining the types of populism in Europe, assessing their electoral strength and their participation in government}

Scholars have always struggled to define the nature of populism; Isaiah Berlin (1968) stated that defining populism is like biting a sour apple due to the difficulty of finding a way to conceal all kinds of manifestations related to populism. In this regard, one of the main features of populism is its 'chameleonic' (Taggart 2000) essence. More recently, the literature has identified four core populist features: (1) the central position of the people; (2) the homogeneity of the people; (3) antielitism; and (4) a sense of perceived political, economic and cultural crisis related to 


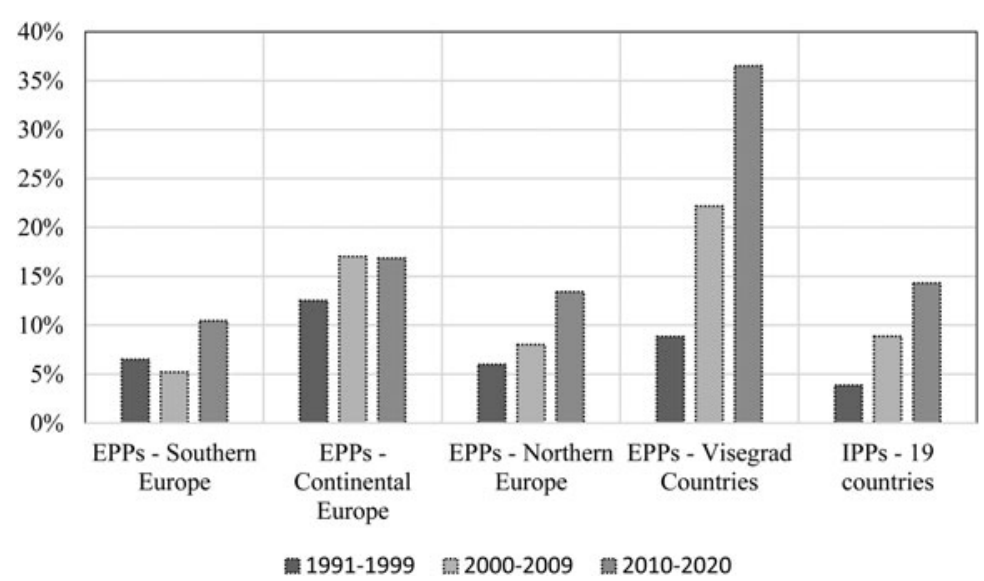

Figure 1. Electoral Results of Exclusionary (EPPS) and Inclusionary (IPPs) Populist Parties in 19 Countries Source: Electoral results from Döring and Manow (2020); case selections from Roodujin et al. (2019). Note: See Online Appendix, Table $1 \mathrm{~A}$ for the whole list.

the exploitation of the people (Mudde 2004; Rooduijn 2013). Following the thincentred ideology approach proposed by Cas Mudde (2004), another important feature of populism is that it is frequently accompanied by a hosting ideology which complements those ideological aspects that populism does not include.

Focusing on the hosting ideology as the main classificatory characteristic, the literature has identified in the exclusionary and inclusionary traits (Font et al. 2019; Mudde and Rovira Kaltwasser 2012b) the most relevant distinction between populist types. A less recurrent type in Europe is the so-called neoliberal populism (Pauwels 2010; Weyland 1999). Exclusionary populists are usually associated with parties belonging to the radical right party family: as a nativist party family (Mudde 2007), populist radical right parties target the outgroups, such as immigrants and 'other' minorities who cannot belong to the 'real' people. Being excluded from the 'people' implies that these 'outsiders' cannot have the same political and economic rights as the 'people': the 'in-group' has strict boundaries, whose surveillance is left to the people of the 'in-group'. On the other hand, for inclusionary populists, economic, financial and oftentimes political elites represent the outsiders, as they threaten the unity of the people, perpetuating a system of economic exploitation in which the majority of the people is excluded. Admittedly, this type of antielitism, albeit framed in a different way, is typical of exclusionary populists as well. However, contrary to exclusionary populists, inclusionary populists want to give a voice to disregarded groups, to highlight the 'dignity' of indigenous populations as well as expanding welfare programmes to include the poor (Font et al. 2019). For that reason, inclusionary populism is more frequently associated with radical left (Damiani 2020) and sometimes social democratic parties.

Indeed, populism in Europe has been more frequently associated with radical right parties, not only for their electoral success (van Kessel 2015), but also for the relative marginality of other types of populism (Font et al. 2019). Using the ParlGov data set (Döring and Manow 2020) and the PopuList (Roodujin et al. 2019) (see Online Appendix, Table 1A for the full list), Figure 1 sums up the 
Table 1. Participation of Populist Parties in Government as a Percentage of All Years: with respect to Figure 1

\begin{tabular}{lcccc}
\hline Government typology & $1991-2000$ & $2001-9$ & $2010-19$ & Total 1991-2019 \\
\hline Major partner & 0.0 & 2.3 & 11.1 & 4.5 \\
\hline Junior partner & 5.3 & 8.2 & 12.1 & 8.5 \\
\hline Major partner + Junior Partner & 0.5 & 5.8 & 6.8 & 4.4 \\
\hline External support & 0.5 & 4.7 & 5.8 & 3.6 \\
\hline Total years & 6.3 & 21.0 & 35.8 & 21.1 \\
\hline Years out of government & 93.7 & 79.0 & 64.2 & 78.9 \\
\hline Total & 100.0 & 100.0 & 100.0 & 100.0 \\
\hline
\end{tabular}

Source: Author's own elaboration.

Note: Each country has 29 years in government (551 in total). For each year in government (YG), I compute whether the government in office is either populist or non-populist. In the election years or in the cabinet reshuffle years, I assigned the YG to the government that was in government for the longer part of that year, e.g. if a populist party enters the government in May, succeeding a non-populist government, then the year is counted as if the populists were in government. If a populist party enters the government in October, succeeding a non-populist government, then the year is counted as if non-populists were in government.

electoral results of exclusionary populist parties (EPPs) divided into geographic areas $^{1}$ and inclusionary populist parties (IPPs) in 19 European countries ${ }^{2}$ in the last three decades. Figure 1 shows that EPPs are more successful than IPPs. In particular, in Visegrad countries, EPPs are now the most relevant party family, while the area where EPPs underperformed is Southern Europe, where IPPs have recently accessed power (SYRIZA in Greece in 2015 and Podemos in Spain in 2019).

For the purpose of this article, however, it is also necessary to analyse the presence of populist parties in government, whatever their hosting ideology. Table 2A in the Online Appendix provides a full list of all populist parties in government from 1991 to 2019, while Table 1 shows the frequency of the inclusion of populist parties in government over the last three decades. Table 1 reports the percentage of the years spent in government by populist parties from 1991 to 2019 and also shows the roles of the respective populist parties in governments.

Table 1 reveals that populists have been excluded from government $(78.9 \%$ of the cases in the whole data set) most of the time. However, their presence in European governments became more frequent in the last decade (2010-19): from the first decade (1991-2000) to the last one (2010-19), the share increased by almost 30 percentage points. Populist parties were predominantly junior partners to non-populist parties: in all three decades under consideration this is the government typology which is more frequent. Yet, as of 2018, six countries were ruled by populist major partners (in three cases in coalition with populist junior partners) (see Online Appendix Table 2A).

\section{Populism in government: a threat to liberal democracy?}

The literature has thus far produced several 'normative' or 'ideal' definitions of democracy - that is, definitions of democracy with adjectives, which by their nature 
cannot be realized in full, but whose actual implementation can be empirically tested (Dahl 1989; Sartori 1987a). For example, Leonardo Morlino (2011) identifies eight ideal types, among which he includes liberal democracy, while Michael Coppedge et al. (2011) find six types. These ideal types expand the minimal (procedural) conceptions of democracy, like the ones identified by Joseph Schumpeter (1942) or by Robert Dahl (1971). Following Dahl (1971), the liberal democratic ideal type is structured by eight institutional guarantees that are aimed at freely selecting candidates in order to realize majority rule through a fair procedure (electoral campaign), while at the same time protecting minority rights in order to avoid the tyranny of the majority. ${ }^{3}$ Thus, liberal democratic systems combine liberty and equality, since 'all equalities are not democratic acquisitions, just as all freedoms are not liberal conquests' (Sartori 1987b: 384).

If the liberal democratic ideal type balances the majority rule - the most basic assumption for a democracy without adjectives is that all power goes to all people (Sartori 1987a: 45) - and equal and fair participation, pluralism (in the media and in political representation) and the protection of minorities are its main corollary. Since one of the defining features of populism, as highlighted above, is its peoplecentrism - that is, treating the polity as a non-conflictual and homogeneous body one may wonder what the relation is between populism and a political regime that (ideally) recognizes and protects pluralism. The most straightforward answer to this question is that the two concepts are antonyms and indeed Takis Pappas (2016a) has defined populism as political illiberalism, precisely for the conflictual nature between the pluralist dimension of liberalism and the people-centrist monism of populism.

Yet, populism has been perceived as a corrective to how liberal democracy works in real life: as Cas Mudde and Cristóbal Rovira Kaltwasser (2012a: 17) put it, 'the ambivalence of the relationship is directly related to the internal contradiction of liberal democracy, that is, the tension between the democratic promise of majority rule and the reality of constitutional protection of minority rights'. Moreover, the inherent tension between populism and other qualities of the liberal democratic regime is well-known (Canovan 1999; Plattner 2010): as the increasing inclusion of the people within democratic institutions implies that the democratic process becomes less intelligible and transparent (Canovan 2002), populism finds a fertile ground for targeting several procedural and substantial aspects of the democratic decision-making architecture, their most fundamental criticism being of representative politics (Taggart 2004). The hostility towards representative politics derives from the populist conception of the 'people' as a homogeneous identity that the corrupt elites try to split for their own interests (Mudde 2004). For critics of populism, the idea of a homogeneous polity conflicts with the basic principle of pluralism as well (Abts and Rummens 2007; Pappas 2016a; Rummens and Abts 2010; Urbinati 2013). This is not to say that populism is non-democratic per se when it comes to political representation (Mudde and Rovira Kaltwasser 2012a; Müller 2016), since populist parties do participate in the elections and do not mean to overthrow the democratic institutions as such (Mény and Surel 2002).

On the other hand, populism is also seen as a potential 'corrective' for democracy, especially when it comes to participation of the excluded groups, political mobilization of neglected issues (Laclau 2005) and the non-mediated involvement 
of the 'people' in decision-making (Vittori 2017): the unfulfilled promises that democratic institutions generate (Canovan 1999) may be delivered by a populist appeal to participation (Laclau 2005), as populism in this interpretation allows the 'people' to take back politics from below (Mouffe 2018). Opponents of such a view claim that this type of populist mobilization hides an ultra-majoritarian view of society, in which minorities (in the case of EPPs) are excluded from the people (Plattner 2010).

To sum up, populism is expected to impact democratic institutions in four respects: the first concerns the concept of political representation of the 'homogeneous people', from which it derives a second aspect: either the lack of protection for minority groups in the case of EPPs or, conversely, their inclusion in the polity in the case of IPPs. The third concerns the concept of pluralism, since pluralism conflates with the homogeneity of the people principle (Pappas 2016a), and the fourth concerns participation, as populists are believed potentially to mobilize disenfranchised sectors of society (Laclau 2005).

Besides the normative debate, the most comprehensive study on populists in government in Latin America found that 'populist rule has had largely negative effects on the legal and institutional constraints' and that 'populist governments fail to enhance participation' (Houle and Kenny 2018: 280-281). A similar conclusion is reached in another comprehensive work (Huber and Schimpf 2016b) on nine countries in Latin America: populism in government harms the democratic quality of a country. Yet, populism in opposition is found to have a positive effect. In the European case, recent analyses on the relationship between the quality of democracy and populism show that, contrary to Latin American populism, the presence of populism in government does not lead to a complete breakdown or the erosion of democracy (Huber and Schimpf 2016b, 2017b). However, it was also found that right-wing populism in government has a much more negative effect on minority rights compared with left-wing populism, while the 'mutual constraints' quality, which measures the relevant counter-powers in a given political system, is not affected by left or right hosting ideology (Huber and Schimpf 2016a; Spittler 2018). Moreover, the rule of law is not affected by right-wing populism in government while, when it comes to political participation, populists' electoral strength actually boosts (electoral) participation (Spittler 2018). This latter finding shows how populism can be analysed as a 'corrective' to liberal democracy. However, Marcus Spittler (2018) also found that right-wing populist parties are a 'threat' due to their negative influence on individual liberties.

\section{Hypotheses}

As explained in the previous section, the literature has highlighted the existence of three competing hypotheses about populism: (1) populism as a threat to democracy; (2) populism as a corrective to democracy; and (3) populism as a threat and a corrective to democracy.

As this article deals with populism in government and the evidence provided so far on the impact of populism on the qualities of democracy has been mixed (see above) - yet oriented towards privileging Hypotheses 1 and 3 - I will use the first hypothesis as a point of reference to test whether populism has a negative impact 
on the qualities of democracy. In particular, as recent works have shown, populism negatively affects the qualities of democracy, but without causing democratic breakdown per se (Huber and Schimpf 2016b, 2017b). Thus, I expect that:

Hypothesis 1: Regardless of the hosting ideology, populists in government impact the qualities of democracy more negatively than non-populist governments do.

However, populist parties do not always have the same role when in government, as the earlier section has shown. Populist parties have been in opposition, for the most part, but they also provide external support to non-populist governments, they have been junior and major partners in coalition governments or have governed alone or with another populist party. Different roles should have different impacts, as providing external support to a government cannot have the same impact on policymaking as being a junior/major partner or governing in a single-party government. In particular, the literature has shown that radical right junior partners were not usually able markedly to influence policies related to immigration (Akkerman 2012) and that junior partners are frequently less able to deliver and are thus punished in the elections following their entrance into government (Klüver and Spoon 2020). The literature on populism has not explored this issue yet, so the main general expectation is that different roles in government affect the qualities of democracy in different ways. In order to discriminate between the roles played by populist parties in each polity, I thus expect that:

Hypothesis 2: The more relevant the status of the populist party in government, the higher the (negative) impact on the qualities of democracy.

Related to this hypothesis, another aspect worth investigating is the potentially different impact of the different kinds of populism. To test it, I follow the finding in the literature on the negative impact of radical right parties (Huber and Schimpf 2016a; Spittler 2018), here labelled EPPs. As the earlier section has shown, EPPs are not the only parties which have gained access to government: more recently, IPPs and in some cases other types of populism have entered government, such as neoliberal populism (see above) or the niche techno-populism (Bickerton and Accetti 2018) represented by the Five Star Movement. Following the literature on the negative impact of EPPs on several qualities of democracy (Huber and Schimpf 2016a, 2016b, 2017a; Spittler 2018), I expect that:

Hypothesis 3: EPPs in government have a more detrimental impact on the qualities of democracy than IPPs (and other types of populism).

\section{Data and methods \\ Data}

In order to assess the impact of populism on the qualities of democracy I use the GSoDI data set. ${ }^{4}$ The GSoDI is composed of five main attributes (representative government, fundamental rights, checks on government, impartial administration and participatory engagement), 15 sub-attributes and 96 indicators. The attribute 


\section{Attributes (Representative government, Fundamental rights, Checks on government, Impartial administration, Participatory engagement)}

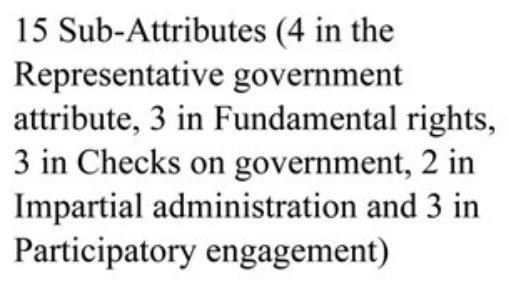

96 indicators (18 in the

Representative government

attribute, 46 in Fundamental rights, 15 in Checks on government, 9 in Impartial administration and 8 in Participatory engagement)

Figure 2. Hierarchy of the Source of GSoDI Data Set Source: Author's own elaboration.

Fundamental Right has eight sub-components which in the ladder of abstraction are located between indicators and sub-attributes (Figure 2).

Rather than focusing solely on the five main dimensions, I select from dimensions, sub-dimensions and indicators those connected with the three main populist dimensions - that is, political representation, pluralism and participation - and those which help to distinguish the impact of EPPs and IPPs (fundamental rights). I include all the main attributes of the GSoDI, except for Impartial Administration, for which no theoretical expectations have been provided in the literature. The main attributes are composite indices, which provide a general overview of each of the four dimensions that constitute a democratic regime. Besides the four macrodimensions of democracy, I add sub-dimensions and sub-attributes to investigate further the specific qualities on which populism in government might have a direct impact. The four main dimensions and the attributes will be divided in the empirical investigation into three broad macro-areas: political representation, pluralism and participation, and the protection of minority rights. The following paragraphs describe the indicators included in the three macro-areas.

\section{Political representation}

Along with the limited majority rule and elective procedures, the representational transmission of power is the backbone of modern (liberal) democracies (Sartori 
1987a). Whether or not populists represent the 'true' people vis-à-vis the elites, the principle of (fair) representation is a conditio sine que non for the analysis of democratic qualities (Dahl 1971). For political representation the main proxy will be the Representative government GSoDI dimension. To this dimension, I add two indicators of the Fundamental rights attribute - Power distributed by social group and Representation of disadvantaged social groups - in order to check for the relationship between political representation and political representation of the minority groups, which in Hypothesis 3 should be negatively related to EPPs in government.

\section{Pluralism and participation}

In a liberal democratic system, there are two main aspects related to pluralism. The first is connected with the liberal concept of 'checks and balances', with which populism has an ambivalent relationship as it constrains in its essence the majority rule and, broadly speaking the 'will of the people' (Rovira Kaltwasser 2014). The second is the (democratic) principle of freedom of expression, under which there should be no impediment for minorities to express their opinions (Dahl 1965). In this regard, the proxies used here are Checks on government and Freedom of expression (a sub-component of the Fundamental rights attribute). One positive aspect which is frequently associated with populism is the inclusion of the people in a more participatory political environment (Mudde and Rovira Kaltwasser 2012a: 20-21). Rather than looking at the electoral turnout only, which is a proxy for political participation - but where the presence of populist parties in the political system might in itself be an incentive to participate in the election, regardless of the parties' inclusion in government - I use the Civil society participation dimension (a sub-attribute of Participatory engagement). ${ }^{5}$ Civil society participation measures the extent to which people are engaged in civil society activities: once in government, populist parties are expected to implement policies that foster participation within society, if populism works as a tool for the mobilization of people (and issues) (Laclau 2005).

\section{Protection of minority rights}

Finally, (exclusionary) populism is also believed to undermine not only political institutions but also the fundamental rights of minorities (Mudde and Rovira Kaltwasser 2012a: 21-22). The protection of minority rights is the most relevant dimension that distinguishes EPPs from IPPs, as EPPs target minorities in order to limit their influence on the polity while IPPs target outgroups as the 'people' to be included in the in-group (Font et al. 2019; Mudde and Rovira Kaltwasser 2012b).

As a proxy for the protection of minority rights, I use more than one dimension in order to check for the multifaceted aspect of this issue; a broad picture can be drawn using the Fundamental rights attribute, yet in order to be more specific about the minority rights, I add Civil liberties, which is a sub-attribute of the Fundamental rights attribute, Social group equality (a sub-component of Fundamental rights) and one indicator of the Social group equality, Social group equality with regard to civil liberties. 


\section{Modelling strategy}

The first hypotheses will be tested in two steps. First, I use a time-series analysis for each indicator and for each country in order to account for the context-dependency of populism (Taggart 2000). The aim is to detect when structural breaks occur in the time span selected for each country. Relying on the Wilkinson-Rogers notation (Wilkinson and Rogers 1973), Achim Zeileis et al. (2002a, 2002b) created a software specification in $\mathrm{R}$ to test the cumulated sums of standard OLS residuals (OLS-based CUSUM test), a test first introduced by Werner Ploberger and Walter Krämer (1992). Structural breaks occur when a time series abruptly changes at a point in time due to an event which the theory and shared knowledge need to identify. As the structural break indicates when a time series significantly changes its 'normal' path, in this specific case, the aim is to assess whether structural breaks occur when populist parties are in government. The coding procedure for associating structural breaks with governments in office can be found in the Online Appendix (see 'Coding procedure for structural breaks').

After detecting the structural breaks, I sum those which occurred during populist and non-populist governments and I derive the structural break/years in government $(\mathrm{SB} / \mathrm{YG})$ ratio. The $\mathrm{SB} / \mathrm{YG}$ ratio divides the total structural breaks by the years in government (derived from the absolute values of Table 1) of populist and non-populist governments. The ratio gives the likelihood of a structural break in a temporal unit. The higher the ratio, the higher the possibility that a structural break occurs and vice versa.

$$
\frac{S B}{Y G} \text { ratio }=\frac{\text { Structural breaks }}{\text { Years in government }}
$$

The second step is focused on panel regression models, in which the dependent variable is represented by the scores of each country in each previously selected indicator. Thus, there are 10 dependent variables, whose values range from 0 to 1 . The main independent variable is a dummy variable indicating whether populist parties are in government $(=0)$ or in opposition $(=1)$. To this, I add other controls. First, the GDP per capita and the unemployment rate (World Bank 2020) are intended to control for the economic performance of the countries; second, the effective number of electoral parties (ENEP) (Gallagher 2019) to control for the fractionalization of the party system, which might reduce the possibility of a nonmainstream party entering government. The third control is the age of the democracy (Boix et al. 2013), as the consolidation of a democracy might temper the influence of populists in government. The fourth is the institutionalization of the party system (Casal Bértoa 2021) - 'the process by which the patterns of interaction among political parties become routine, predictable and stable over time' - as the deinstitutionalization of party systems negatively affects electoral accountability (Mainwaring and Torcal 2006).

To test the second and the third hypotheses, I again use panel regression models with the same dependent variables and the same controls. Unlike the second part of the first hypothesis, one independent variable is different for the second and third hypotheses: the dummy variable measuring the presence of populist parties in 
opposition or in government. In the second hypothesis, this variable has been replaced by the role of populist parties in government. It is a categorical variable distinguishing the role of the populist party in government: as external supporter, as junior partner(s) in a coalition government, as major partner in a coalition government. ${ }^{6}$ In the third hypothesis, it has been replaced by the type of populist party in government. It is a categorical variable with four levels, 'Exclusionary' (reference category), 'Inclusionary', 'Other populists' and 'None' (indicating when populist parties were not included in government). For each model, I run a Hausman test to select the most appropriate model between random- and fixed-effects models.

\section{Results and discussion}

In the first step of the analysis for Hypothesis 1, I check the occurrence of structural breaks and populist parties in government. I focus specifically on negative structural breaks in order to evaluate the alleged negative impact of populism in government on the qualities of democracy. Structural breaks occur more often when populist parties are in government. In the whole period, 32 (43.8\%) negative structural breaks occurred when populist parties were in government and $41(56.1 \%)$ when non-populist parties were in government. ${ }^{7}$

Using the data on structural breaks in Table 2 and Table 1 data on populists' presence in government, it is possible to calculate the SB/YG ratio. Overall, the $\mathrm{SB} / \mathrm{YG}$ ratio for negative structural breaks is 0.276 for populists in government and 0.009 for non-populists.

However, this figure must also be discussed dividing the pre-crisis and the postcrisis scenario (2010-18), as in the latter the percentage of populist parties in government grows substantially (Table 1). The difference is still positive, but the overall picture is less clear cut: the SB/YG ratio is 0.382 for populists and 0.311 for non-populists.

For the second step of the analysis, Table 3 reports the results of the panel regression models for each of the dimensions under analysis. The findings clearly indicate that having populists in government or in opposition matters when it comes to democratic qualities. First, all main GSoDI dimensions are significant and positive (Representative government, Checks on government, Civil society participation and Fundamental rights). Sub-attributes are significant as well: only in one case (third model, Representation of the disadvantaged social groups) is the difference not significant; when it comes to Social group equality with regard to civil liberties the significance is only at the $\mathrm{p}<0.05$ level. Whichever main dimension is under analysis, populism affects the qualities of democracy. Admittedly, the effect is lower than other control variables, such as the institutionalization of the party system. As for party institutionalization, the pattern is almost invariably stable, that is, a higher institutionalization improves the quality of the democracy. Again, the only exception is Representation of the disadvantaged social groups, where the variable is significant, but in the opposite direction. In three other cases, Power distributed by social group, Fundamental rights and Social group equality, the variable is not significant. Overall, the results of the two-step analysis support Hypothesis 1, that populist parties are more harmful to the qualities of democracy than non-populist parties. 
Table 2. Negative and Positive Structural Breaks for 10 Different Indicators of the Quality of Democracy

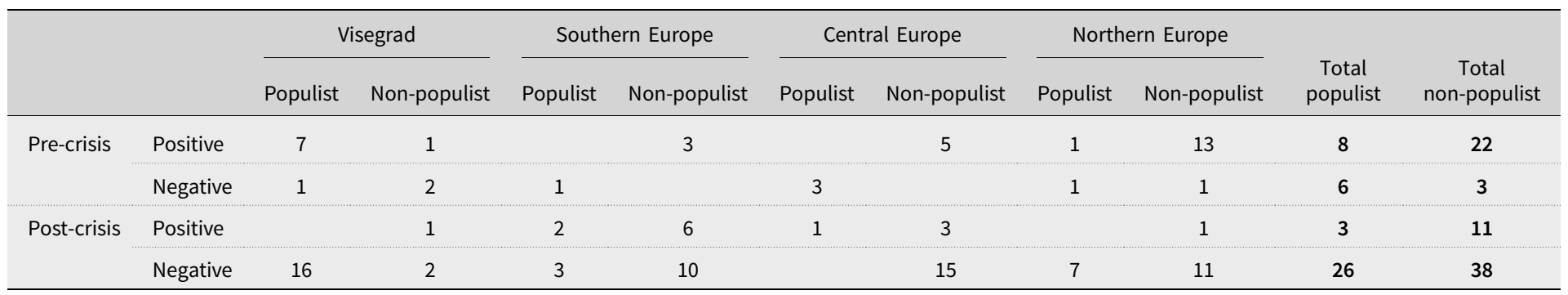

Source: Author's own elaboration from GSoDI data. 
Table 3. Panel Regression Models for 10 Democratic Qualities, Hausman tests to determine whether to use random or fixed effects for each model

\begin{tabular}{|c|c|c|c|c|c|c|c|c|c|c|}
\hline & \multicolumn{10}{|c|}{ Dependent variable: } \\
\hline & \multicolumn{3}{|c|}{ Political representation } & \multicolumn{3}{|c|}{ Pluralism and participation } & \multicolumn{4}{|c|}{ Minority rights protection } \\
\hline & $\begin{array}{c}\text { Repres. } \\
\text { government }\end{array}$ & $\begin{array}{c}\text { Pow. soc. } \\
\text { gr }\end{array}$ & $\begin{array}{l}\text { Rep. dis. } \\
\text { soc. gr. }\end{array}$ & $\begin{array}{l}\text { Check on } \\
\text { gvt }\end{array}$ & $\begin{array}{l}\text { Freedom } \\
\text { express. }\end{array}$ & $\begin{array}{l}\text { Civil soc. } \\
\text { part. }\end{array}$ & $\begin{array}{l}\text { Fundam. } \\
\text { rights }\end{array}$ & $\begin{array}{c}\text { Civil } \\
\text { liberties }\end{array}$ & $\begin{array}{l}\text { Soc. gr. } \\
\text { equality }\end{array}$ & $\begin{array}{l}\text { Soc. gr. equality } \\
\text { civ. lib. }\end{array}$ \\
\hline Populists in gvt & $\begin{array}{l}0.012^{\star * \star} \\
(0.004)\end{array}$ & $\begin{array}{l}0.024^{\star \star \star} \\
(0.009)\end{array}$ & $\begin{array}{c}0.005 \\
(0.008)\end{array}$ & $\begin{array}{l}0.038^{\star \star \star} \\
(0.004)\end{array}$ & $\begin{array}{l}0.038^{\star * \star} \\
(0.006)\end{array}$ & $\begin{array}{l}0.029^{\star \star \star} \\
(0.005)\end{array}$ & $\begin{array}{l}0.017^{\star \star \star} \\
(0.003)\end{array}$ & $\begin{array}{l}0.033^{\star \star \star} \\
(0.005)\end{array}$ & $\begin{array}{l}0.018^{\star \star \star} \\
(0.005)\end{array}$ & $\begin{array}{l}0.017^{\star \star} \\
(0.007)\end{array}$ \\
\hline ENEP & $\begin{array}{r}-0.002 \\
(0.001)\end{array}$ & $\begin{array}{l}-0.013^{\star \star \star} \\
(0.003)\end{array}$ & $\begin{array}{c}-0.003 \\
(0.002)\end{array}$ & $\begin{array}{l}-0.004^{\star \star \star} \\
(0.001)\end{array}$ & $\begin{array}{c}0.001 \\
(0.002)\end{array}$ & $\begin{array}{l}0.008^{\star \star \star} \\
(0.002)\end{array}$ & $\begin{array}{c}0.0001 \\
(0.001)\end{array}$ & $\begin{array}{c}-0.0005 \\
(0.001)\end{array}$ & $\begin{array}{c}-0.001 \\
(0.001)\end{array}$ & $\begin{array}{c}0.003 \\
(0.002)\end{array}$ \\
\hline GDP per capita & $\begin{array}{l}0.040^{\star \star \star} \\
(0.006)\end{array}$ & $\begin{array}{c}0.018 \\
(0.012)\end{array}$ & $\begin{array}{r}-0.003 \\
(0.011)\end{array}$ & $\begin{array}{l}0.017^{\star \star \star} \\
(0.006)\end{array}$ & $\begin{array}{l}0.019^{\star \star} \\
(0.008)\end{array}$ & $\begin{array}{c}-0.003 \\
(0.007)\end{array}$ & $\begin{array}{c}0.002 \\
(0.004)\end{array}$ & $\begin{array}{c}0.012^{\star} \\
(0.006)\end{array}$ & $\begin{array}{l}-0.030^{\star \star \star} \\
(0.006)\end{array}$ & $\begin{array}{l}-0.031^{\star \star \star} \\
(0.009)\end{array}$ \\
\hline Unemployment & $\begin{array}{l}0.019^{\star \star \star} \\
(0.004)\end{array}$ & $\begin{array}{l}-0.028^{\star \star \star} \\
(0.009)\end{array}$ & $\begin{array}{l}0.023^{\star \star \star} \\
(0.008)\end{array}$ & $\begin{array}{l}0.023^{\star \star \star} \\
(0.004)\end{array}$ & $\begin{array}{c}0.008 \\
(0.006)\end{array}$ & $\begin{array}{l}0.031^{\star \star \star} \\
(0.005)\end{array}$ & $\begin{array}{l}0.009^{\star \star \star} \\
(0.003)\end{array}$ & $\begin{array}{l}0.008^{\star} \\
(0.005)\end{array}$ & $\begin{array}{c}0.007 \\
(0.005)\end{array}$ & $\begin{array}{c}0.004 \\
(0.007)\end{array}$ \\
\hline Party instit. & $\begin{array}{l}0.177^{\star \star \star} \\
(0.038)\end{array}$ & $\begin{array}{c}0.133 \\
(0.080)\end{array}$ & $\begin{array}{l}-0.298^{\star \star \star} \\
(0.073)\end{array}$ & $\begin{array}{l}0.235^{\star \star \star} \\
(0.040)\end{array}$ & $\begin{array}{l}0.263^{\star \star \star} \\
(0.053)\end{array}$ & $\begin{array}{l}0.094^{\star \star} \\
(0.045)\end{array}$ & $\begin{array}{c}0.014 \\
(0.026)\end{array}$ & $\begin{array}{l}0.207^{\star \star \star} \\
(0.044)\end{array}$ & $\begin{array}{c}0.069 \\
(0.043)\end{array}$ & $\begin{array}{l}0.199^{\star \star \star} \\
(0.065)\end{array}$ \\
\hline Age democracy & $\begin{array}{l}-0.038^{\star \star \star} \\
(0.008)\end{array}$ & $\begin{array}{l}-0.052^{\star \star \star} \\
(0.017)\end{array}$ & $\begin{array}{c}-0.046^{\star \star \star} \\
(0.015)\end{array}$ & $\begin{array}{l}-0.033^{\star \star *} \\
(0.009)\end{array}$ & $\begin{array}{l}-0.056^{\star \star \star} \\
(0.011)\end{array}$ & $\begin{array}{c}0.007 \\
(0.010)\end{array}$ & $\begin{array}{c}0.001 \\
(0.006)\end{array}$ & $\begin{array}{c}-0.045^{\star \star \star} \\
(0.009)\end{array}$ & $\begin{array}{l}0.022^{\star \star} \\
(0.009)\end{array}$ & $\begin{array}{l}0.031^{\star \star} \\
(0.014)\end{array}$ \\
\hline Observations & 494 & 494 & 494 & 494 & 494 & 494 & 494 & 494 & 494 & 494 \\
\hline $\mathrm{R}^{2}$ & 0.175 & 0.120 & 0.199 & 0.279 & 0.197 & 0.221 & 0.097 & 0.210 & 0.108 & 0.079 \\
\hline Adjusted $\mathrm{R}^{2}$ & 0.133 & 0.075 & 0.158 & 0.242 & 0.156 & 0.181 & 0.051 & 0.169 & 0.063 & 0.032 \\
\hline $\begin{array}{l}\text { F Statistic } \\
(\mathrm{df}=6 ; 469)\end{array}$ & $16.619^{\star \star \star}$ & $10.647^{\star \star \star}$ & $19.409^{\star \star \star}$ & $30.176^{\star \star \star}$ & $19.208^{\star \star \star}$ & $22.190^{\star \star \star}$ & $8.409^{\star \star \star}$ & $20.721^{\star \star \star}$ & $9.503^{\star \star \star}$ & $6.746^{\star \star \star}$ \\
\hline
\end{tabular}

Note: ${ }^{\star \star \star} p<0.001 ;{ }^{\star \star} p<0.05 ;{ }^{\star} p<0.1$. 
Populists' role in government: Political Representation
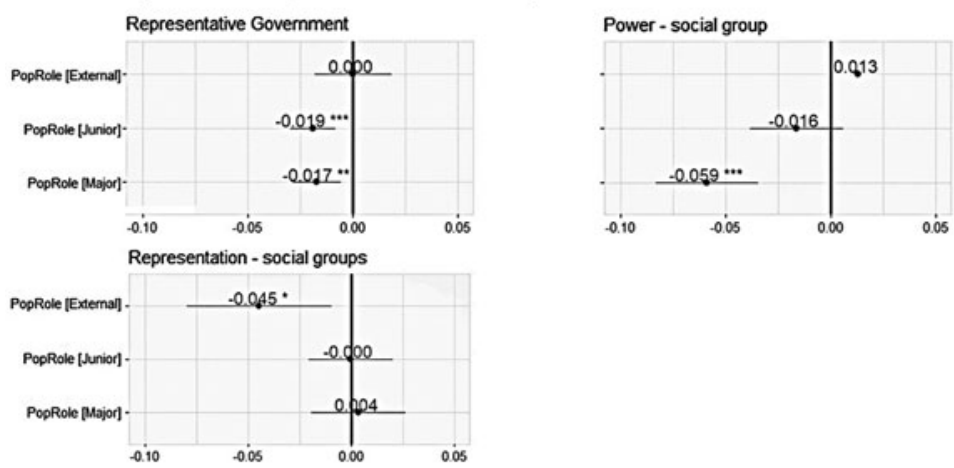

\section{Populists' role in government: Pluralism and Participation}
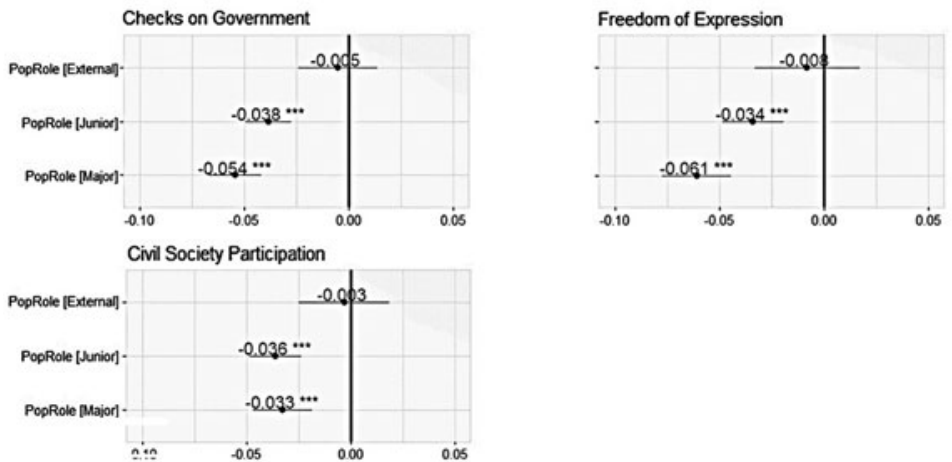

Populists' role in government: Minority rights
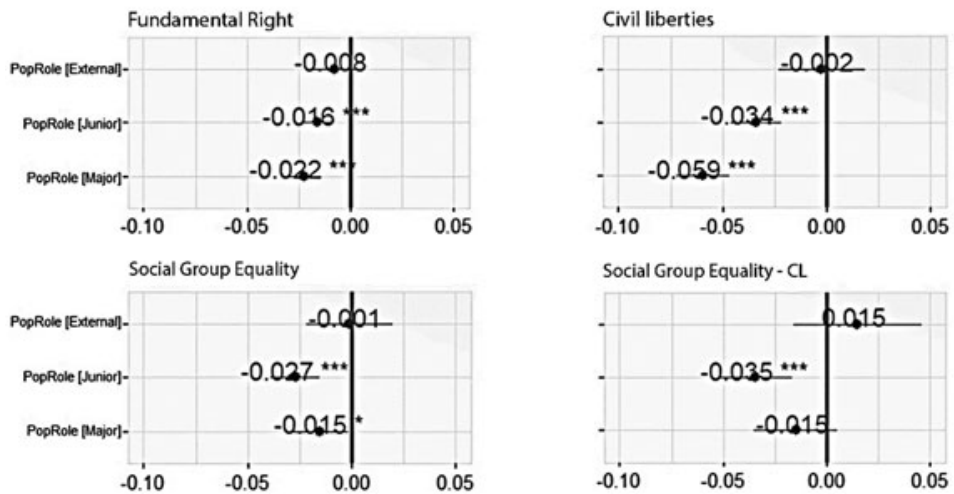

Figure 3. Effects of the Categorical Variable Populists' Role in Government in Panel Regression Models for 10 Democratic Qualities Note: Full model specifications are available in the Online Appendix (Table 4A).

For the second hypothesis, Figure 3 shows the different impact of the role of populist parties in government, compared with when they were not included in the government (full model specification can be found in the Online Appendix, 
Table 4A). The results are mixed: in the political representation and protection of minority rights macro-areas evidence is weaker than in the pluralism macro-area. Specifically, in two cases (Representative government and Power distributed by social group) of the political representation macro-area there are non-statistically significant differences between external supporters and when populists are not included in the government, while in the third dimension (Representation of disadvantaged social groups), external supporters are the only group which differ statistically ( $\mathrm{p}<$ 0.1). As for the protection of minority rights, on the other hand, only Civil liberties has a monotonical direction in which the more relevant the role the higher the (negative) impact. In the case of Fundamental rights, the effect of junior and major categories is almost the same. The two qualities related to Social group equality show a different pattern and, in both cases, the major partner category does not differ at the 0.001 level with respect to the reference category.

In the four models of the minority rights protection macro-area there is no statistical difference between external supporters and the reference category. Nonetheless, the pattern is clearer for the pluralism macro-area, especially in the Checks on government and Freedom of expression dimensions. Civil society participation is, in this regard, deviant as junior partners have a larger negative effect than major partners do. In these three cases, again, there are no differences between external supporters and the reference category. Overall, the evidence points to partially confirming Hypothesis 2, even though the results are not univocal: the main dimensions of the GSoDI data set (Representative government, Checks on government, Civil society participation and Fundamental rights) indicate a clear-cut distinction between external supporters and other forms of involvement, yet the difference between being a major or a junior partner is less evident. The subdimensions, on the other hand, have no clear-cut pattern.

Finally, the evidence supporting Hypothesis 3 is robust, yet not univocal (Figure 4, full model specifications can be found in the Online Appendix, Table 5A). Following the empirical results for Hypothesis 1, it emerges that populist parties have a negative impact on the qualities of democracies, compared with governments with no populists. When restricting the focus to a comparison between EPPs and the 'None' category - that is, when populists are not included in the government - the difference is robust. Only the Representation of disadvantaged social groups category is non-significant; all other qualities are positive and significant at either the $\mathrm{p}<0.05$ or $\mathrm{p}<0.01$ levels, meaning that having EPPs excluded from government increases the qualities of democracy. A similar, yet non-identical, pattern can be found when comparing EPPs with other populist parties in government: in this case, however, the two indicators in the political representation dimension and, more importantly, the Checks on government, are not significant. Overall, populist parties in the 'Other' category perform far better when it comes to the minority rights protection macro-area. The main issue under investigation in Hypothesis 3 is the comparison between EPPs and IPPs: in this regard, the main dimensions of the GSoDI (Representative government, Checks on government, Civil society participation and Fundamental rights) in the three macro-areas are significant and positive. As for the other subdimensions, in one case the difference is significant, but negative (Power distributed by social group), in two cases EPPs and IPPs do not diverge statistically 

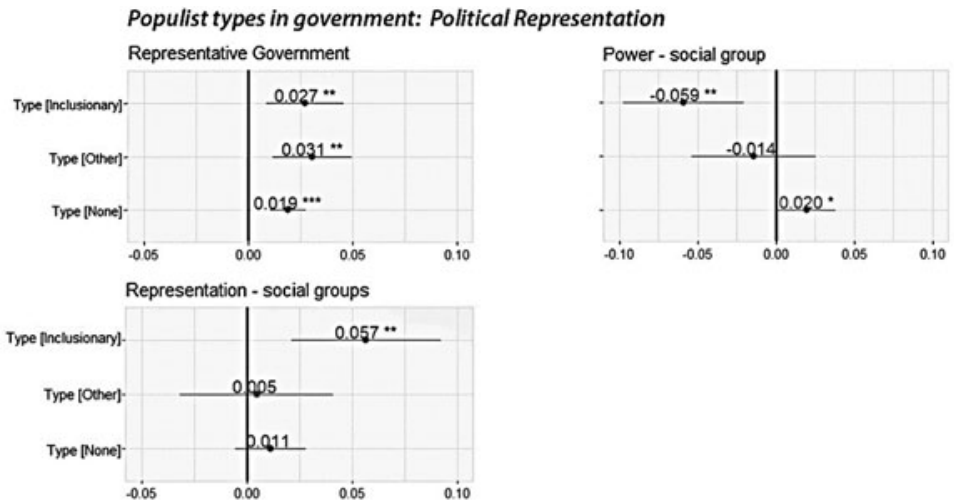

Populist types in government: Pluralism and Participation
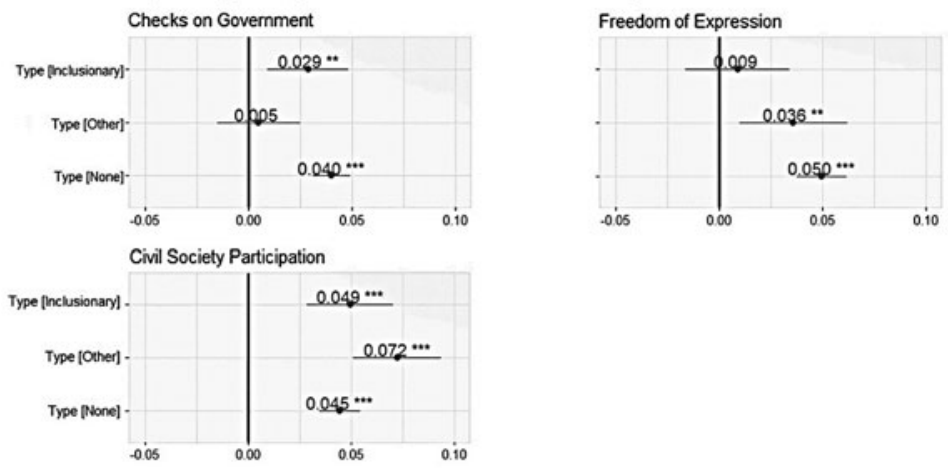

Populist types in government: Minority rights
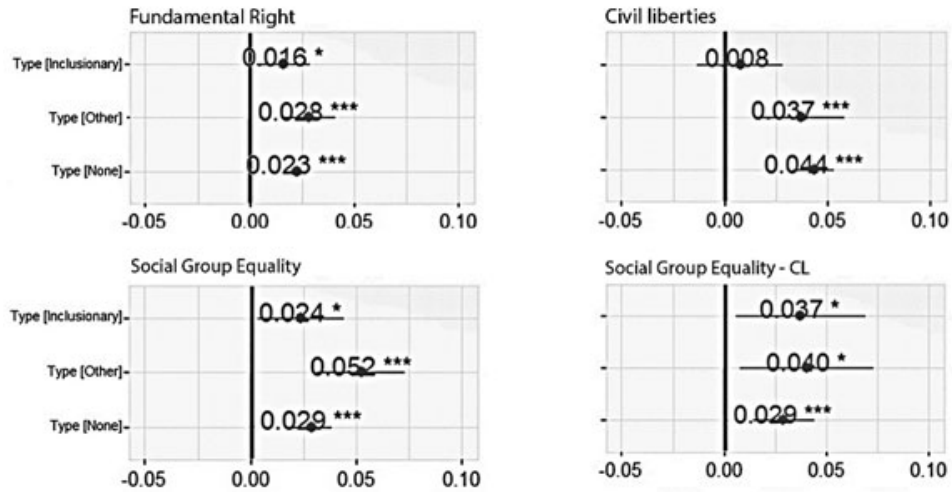

Figure 4. Effects of the Categorical Variable Populist Types in Panel Regression Models for 10 Democratic Qualities

Note: Full model specifications are available in the Online Appendix (Table 5A).

(Freedom of expression and Civil liberties) and in two others the difference is positive and significant at $\mathrm{p}<0.05$ level (the two Social group equality indicators). In conclusion, while IPPs have a more positive impact on the most relevant 
dimensions of democracies compared with EPPs, the empirical findings are not as strong as the ones identified in Hypothesis 1.

\section{Conclusions}

The debate about the impact of populism on liberal democracy is long-standing. In the literature, populism has been regarded as a threat, a corrective, and a threat and corrective to democracy. Starting from the most recent comparative literature on the topic, this article has addressed the question of whether populist parties affect (negatively or positively) the qualities of liberal democracy when in government, whether their role in government matters and whether specific types of populist parties, namely EPPs, have a more negative impact than other types. In order to answer these questions, I first provided a new descriptive analysis of the inclusion of populist parties in government, showing that populist parties' electoral success in the last decade coincided with the increasing inclusion in (coalition) government of these parties. Second, using the GSoDI data set, I found strong empirical confirmation of the fact that populists in government impact liberal democratic qualities more negatively than non-populists do. Additionally, I tested the impact of populism depending on the role of populist parties in government.

The results show that role matters only to a limited extent: if populist parties are external supporters, their impact on the quality of democracy is the same as if they were not included in government. It is less clear whether being a major or a junior partner makes a difference, when compared with being in opposition: in some cases, the difference is not relevant, yet in other important democratic dimensions such as Checks on government, Freedom of expression, Fundamental rights and Civil liberties the pattern indicates that major partners impact more negatively than junior partners. Finally, I show that, while EPPs have a more negative impact on the qualities of democracies than populists in opposition and other (residual) types of populism, the evidence supporting the thesis that EPPs have a different impact from IPPs is less robust, albeit present. Overall, IPPs' footprint on the qualities of democracy is less negative than EPPs, especially when looking at the most relevant dimensions under analysis. However, in at least three dimensions this is not the case.

These findings have important implications for the study of populism: first, among the various interpretations of the relationship between populism and liberal democracy, the 'threat' argument has the most solid empirical ground. This, however, might also mean that populist parties are capable of delivering, if their aim is to reverse or transform liberal democracy in Europe. Needless to say, populism is not against liberal democratic values tout court, but if the goal of populist parties is to antagonize some values of the liberal democracy, then this article shows that they have been fulfilling their aim so far. More specifically and in line with the previous literature (Huber and Schimpf 2016a, 2017a; Spittler 2018), the results show that EPPs in particular have a bigger impact than the other cases: even though EPPs are increasingly involved in government and the break of the so-called cordon sanitaire to impede these parties' access to power is no longer taboo, their inclusion means a deterioration in the qualities of liberal democracy. This might be proof that EPPs and populists in general are the only actors in Europe capable of reversing 
specific aspects of liberal democracy, as more and more voters have apparently been demanding for several decades now. It might also mean that their presence in government ends up being a threat to the very essence of liberal democracy.

Supplementary material. To view the supplementary material for this article, please go to: https://doi. org/10.1017/gov.2021.21.

Acknowledgements. This work was supported by the European Research Council (ERC) under the European Union's Horizon 2020 research and innovation programme for the project 'CURE OR CURSE?' (grant number 772695).

\section{Notes}

1 Northern countries include Denmark, Norway, Sweden, Finland, the UK and Ireland. Continental countries: France, Germany, Belgium, Austria, Switzerland. Southern countries: Portugal, Spain, Italy, Greece. Visegrad countries: Hungary, Poland, Czech Republic, Slovakia.

2 The low number of inclusionary populist parties does not allow a meaningful distinction between geographical areas. For the case selection see Table 1A in the Online Appendix.

3 The eight institutional guarantees are: freedom to form and join organizations, freedom of expression, right to vote, right of political leaders to compete for votes, eligibility for public office, alternative sources of information, free and fair elections, institutions for making government policies dependent on votes and other expressions of preference.

4 For the technical procedures in constructing the indices see Tufis (2019).

5 Civil society participation is used as a proxy of Participatory engagement, which is not an attribute like the others mentioned in Figure 2 as the four sub-attributes that compose it are not merged together to create a higher-rank attribute.

6 This category also includes those cases in which governments are composed of a major populist partner and a junior populist party at the same time.

7 For the full list of structural breaks see the Online Appendix, Table 3A.

\section{References}

Abts K and Rummens S (2007) Populism Versus Democracy. Political Studies 55(2), 405-424. https://doi. org/10.1111/j.1467-9248.2007.00657.x.

Akkerman T (2012) Comparing Radical Right Parties in Government: Immigration and Integration Policies in Nine Countries (1996-2010). West European Politics 35(3), 511-529. https://doi.org/10. 1080/01402382.2012.665738.

Akkerman T, De Lange SL and Rooduijn M (2016) Radical Right-Wing Populist Parties in Western Europe: Into the Mainstream? Abingdon: Routledge.

Berlin I (1968) To Define Populism. Government and Opposition: An International Journal of Comparative Politics 3(2), 137-180. https://doi.org/10.1111/j.1477-7053.1968.tb01332.x.

Bickerton CJ and Accetti CI (2018) 'Techno-Populism' as a New Party Family: The Case of the Five Star Movement and Podemos. Contemporary Italian Politics 10(2), 132-150. https://doi.org/10.1080/ 23248823.2018.1472919.

Boix C, Miller M and Rosato S (2013) A Complete Data Set of Political Regimes, 1800-2007. Comparative Political Studies 46(12), 1523-1554. https://doi.org/10.1177/0010414012463905.

Canovan M (1999) Trust the People! Populism and the Two Faces of Democracy. Political Studies 47(1), 2-16. https://doi.org/10.1111/1467-9248.00184.

Canovan M (2002) Taking Politics to the People: Populism as the Ideology of Democracy. In Mény Y and Surel Y (eds), Democracies and the Populist Challenge. Basingstoke: Palgrave Macmillan, pp. 25-44.

Casal Bértoa F (2021) The Database of who Governs in Europe and Beyond. Party Systems and Government Observatory. https://whogoverns.eu.

Castanho Silva B et al. (2020) An Empirical Comparison of Seven Populist Attitudes Scales. Political Research Quarterly 73(2), 409-424. https://doi.org/10.1177/1065912919833176. 
Coppedge M et al. (2011) Conceptualizing and Measuring Democracy: A New Approach. Perspectives on Politics 9(2), 247-267. https://doi.org/10.1017/S1537592711000880.

Dahl RA (1965) Reflections on Opposition in Western Democracies. Government and Opposition: An International Journal of Comparative Politics 1(1), 7-24. https://doi.org/10.1111/j.1477-7053.1965. tb00362.x.

Dahl RA (1971) Polyarchy; Participation and Opposition. New Haven: Yale University Press.

Dahl RA (1989) Democracy and Its Critics. New Haven: Yale University Press.

Damiani M (2020) Populist Radical Left Parties in Western Europe. Abingdon: Routledge.

Döring H and Manow P (2020) Parliaments and Governments Database (ParlGov): Information on Parties, Elections and Cabinets in Modern Democracies. Development version. www.parlgov.org.

Font N, Graziano P and Tsakatika M (2019) Varieties of Inclusionary Populism? SYRIZA, Podemos and the Five Star Movement. Government and Opposition: An International Journal of Comparative Politics, published early online, May. https://doi.org/10.1017/gov.2019.17.

Gallagher M (2019) Election Indices Dataset. www.tcd.ie/Political_Science/people/michael_gallagher/ ElSystems/index.php.

Hawkins KA, Carlin RE, Littvay L and Kaltwasser CR (2018) The Ideational Approach to Populism. Abingdon: Routledge.

Houle C and Kenny PD (2018) The Political and Economic Consequences of Populist Rule in Latin America. Government and Opposition: An International Journal of Comparative Politics 53(2), 256-287. https://doi.org/10.1017/gov.2016.25.

Huber RA and Schimpf CH (2016a) A Drunken Guest in Europe? The Influence of Populist Radical Right Parties on Democratic Quality. Zeitschrift Für Vergleichende Politikwissenschaft 10, 103-129. https://doi. org/10.1007/s12286-016-0302-0.

Huber RA and Schimpf CH (2016b) Friend or Foe? Testing the Influence of Populism on Democratic Quality in Latin America. Political Studies 64(4), 872-889. https://doi.org/10.1111/1467-9248.12219.

Huber RA and Schimpf CH (2017a) On the Distinct Effects of Left-Wing and Right-Wing Populism on Democratic Quality. Politics and Governance 5(4), 146-165. https://doi.org/10.17645/pag.v5i4.919.

Huber RA and Schimpf CH (2017b) Populism and Democracy - Theoretical and Empirical Considerations. In Heinisch RCH, Holtz-Bacha $\mathrm{CH}-\mathrm{B}$ and Mazzoleni O (eds), Political Populism. Baden-Baden: Nomos, pp. 329-344.

Jagers J and Walgrave S (2007) Populism as Political Communication Style: An Empirical Study of Political Parties' Discourse in Belgium. European Journal of Political Research 46(3), 319-345. https:// doi.org/10.1111/j.1475-6765.2006.00690.x.

Jansen RS (2011) Populist Mobilization: A New Theoretical Approach to Populism. Sociological Theory 29(2), 75-96. https://doi.org/10.1111/j.1467-9558.2011.01388.x.

Klüver H and Spoon JJ (2020) Helping or Hurting? How Governing as a Junior Coalition Partner Influences Electoral Outcomes. Journal of Politics 82(4), 1231-1242. https://doi.org/10.1086/708239.

Laclau E (2005) On Populist Reason. London: Verso.

Laclau E (2006) Why Constructing a People is the Main Task of Radical Politics. Critical Inquiry 32(4), 646-680. https://doi.org/10.1086/508086.

Louwerse T and Otjes S (2019) How Populists Wage Opposition: Parliamentary Opposition Behaviour and Populism in Netherlands. Political Studies 67(2), 479-495. https://doi.org/10.1177/0032321718774717.

Mainwaring S and Torcal M (2006) Party System Institutionalization and Party System Theory after the Third Wave of Democratization. In Katz RS and Crotty W (eds), Handbook of Party Politics. Thousand Oaks: Sage, pp. 204-218.

Mény Y and Surel Y (2002) The Constitutive Ambiguity of Populism. In Mény Y and Surel Y (eds), Democracies and the Populist Challenge. Basingstoke: Palgrave Macmillan, pp. 1-21.

Moffitt B (2016) The Global Rise of Populism: Performance, Political Style, and Representation. Stanford: Stanford University Press.

Morlino L (2011) Changes for Democracy: Actors, Structures, Processes. Oxford: Oxford University Press.

Mouffe C (2018) For a Left Populism. London: Verso.

Mudde C (2004) The Populist Zeitgeist. Government and Opposition: An International Journal of Comparative Politics 39(4), 541-563. https://doi.org/10.1111/j.1477-7053.2004.00135.x.

Mudde C (2007) Populist Radical Right Parties in Europe. Cambridge: Cambridge University Press. 
Mudde C and Rovira Kaltwasser C (2012a) Populism in Europe and the Americas. Cambridge: Cambridge University Press.

Mudde C and Rovira Kaltwasser C (2012b) Exclusionary vs. Inclusionary Populism: Comparing Contemporary Europe and Latin America. Government and Opposition: An International Journal of Comparative Politics 48(2), 147-174. https://doi.org/10.1017/gov.2012.11.

Müller J-W (2016) What is Populism? Philadelphia: University of Pennsylvania Press.

Pappas TS (2016a) Modern Populism: Research Advances, Conceptual and Methodological Pitfalls, and the Minimal Definition. In Thompson W et al. (eds), Oxford Research Encyclopedia of Politics. Oxford: Oxford University Press. https://oxfordre.com/politics.

Pappas TS (2016b) The Specter Haunting Europe: Distinguishing Liberal Democracy's Challengers. Journal of Democracy 27(4), 22-36. https://doi.org/10.1353/jod.2016.0059.

Pauwels T (2010) Explaining the Success of Neo-Liberal Populist Parties: The Case of Lijst Dedecker in Belgium. Political Studies 58(5), 1009-1029. https://doi.org/10.1111/j.1467-9248.2009.00815.x.

Plattner MF (2010) Democracy's Past and Future: Populism, Pluralism, and Liberal Democracy. Journal of Democracy 21(1), 81-92. https://doi.org/10.1353/jod.0.0154.

Ploberger W and Krämer W (1992) The CUSUM Test with OLS Residuals. Econometrica 60(2), 271-285.

Rooduijn M (2013) The Nucleus of Populism: In Search of the Lowest Common Denominator. Government and Opposition: An International Journal of Comparative Politics 49(4), 572-598. https:// doi.org/10.1017/gov.2013.30.

Rooduijn M, de Lange SL and van der Brug W (2014) A Populist Zeitgeist? Programmatic Contagion by Populist Parties in Western Europe. Party Politics 20(4), 563-575. https://doi.org/10.1177/ 1354068811436065.

Rooduijn M, Van Kessel S, Froio C et al. (2019) The PopuList: An Overview of Populist, Far Right, Far Left and Eurosceptic Parties in Europe. www.popu-list.org.

Rovira Kaltwasser CR (2012) The Ambivalence of Populism: Threat and Corrective for Democracy. Democratization 19(2), 184-208. https://doi.org/10.1080/13510347.2011.572619.

Rovira Kaltwasser CR (2014) The Responses of Populism to Dahl's Democratic Dilemmas. Political Studies 62(3), 470-487. https://doi.org/10.1111/1467-9248.12038.

Rovira Kaltwasser CR and Taggart P (2016) Dealing with Populists in Government: A Framework for Analysis. Democratization 23(2), 201-220. https://doi.org/10.1080/13510347.2015.1058785.

Rummens S (2017) Populism as a Threat to Liberal Democracy. In Kaltwasser C, Taggart P, Ochoa Espejo P and Ostiguy P (eds), The Oxford Handbook of Populism. Oxford: Oxford University Press, pp. 554570 .

Rummens S and Abts K (2010) Defending Democracy: The Concentric Containment of Political Extremism. Political Studies 58(4), 649-665. https://doi.org/10.1111/j.1467-9248.2009.00809.x.

Sartori G (1987a) The Theory of Democracy Revisited: Part One. London: Chatham House Publishers.

Sartori G (1987b) The Theory of Democracy Revisited: Part Two: The Classical Issues. London: Chatham House Publishers.

Schumpeter JA (1942) Capitalism, Socialism and Democracy. New York: Harper and Brothers.

Spittler M (2018) Are Right-Wing Populist Parties a Threat to Democracy? In Kneip S and Merkel W (eds), Democracy and Crisis. New York: Springer, pp. 97-121.

Taggart P (2000) Populism. Milton Keynes: Open University Press.

Taggart P (2004) Populism and Representative Politics in Contemporary Europe. Journal of Political Ideologies 9(3), 269-288. https://doi.org/10.1080/1356931042000263528.

Tufis C (2019) The Global State of Democracy Indices Codebook, Version 3. Stockholm: International IDEA. https://doi.org/10.31752/idea.2019.40.

Urbinati N (2013) The Populist Phenomenon. Raisons Politiques 51(3), 137-154. https:/doi.org/10.3917/ rai.051.0137.

Van Kessel S (2015) Populist Parties in Europe: Agents of Discontent? London: Palgrave Macmillan

Vittori D (2017) Re-Conceptualizing Populism: Bringing a Multifaceted Concept Within Stricter Borders. Revista Espanola de Ciencia Politica 44(1), 43-65. https://doi.org/10.21308/recp.44.02.

Vittori D (2020) The Impact of Populism on Party Organization? A Study of Four Southern European 'Populist' Parties. European Politics and Society 21(1): 53-71. https://doi.org/10.1080/23745118.2019. 1602925. 
Weyland K (1999) Neoliberal Populism in Latin America and Eastern Europe. Comparative Politics 31(4), 379-401. https://doi.org/10.2307/422236.

Wilkinson GN and Rogers CE (1973) Symbolic Description of Factorial Models for Analysis of Variance. Applied Statistics 22(3), 392-399.

World Bank (2020) Unemployment, Total (\% of total labor force) (modeled ILO estimate). https://data. worldbank.org/indicator/SL.UEM.TOTL.ZS.

Zeileis A et al. (2002a) Testing and Dating of Structural Changes in Practice. Computational Statistics and Data Analysis 44(1-2), 109-123. https://doi.org/10.1016/S0167-9473(03)00030-6.

Zeileis A et al. (2002b) strucchange: An R Package for Testing for Structural Change in Linear Regression Models. Journal of Statistical Software 7(2), 1-38. http://www.jstatsoft.org/v07/i02/.

Cite this article: Vittori D (2022). Threat or Corrective? Assessing the Impact of Populist Parties in Government on the Qualities of Democracy: A 19-Country Comparison. Government and Opposition: An International Journal of Comparative Politics 57, 589-609. https://doi.org/10.1017/gov.2021.21 